\title{
A Historical Analysis Of The Post- Apartheid Dispensation Education In South Africa (1994-2011)
}

N. Mouton, North-West University, South Africa G.P. Louw, North-West University, South Africa G.L. Strydom, North-West University, South Africa

\begin{abstract}
The period 1994-2011 introduced a new historical era for school education in South Africa. Outcomes-based Education (OBE) was introduced and was controversial from the outset for educators and policymakers alike. The reason given for the implementation of OBE was to move away from the apartheid curriculum and to address skills, knowledge and values. However, there were various shortcomings and many implementation problems that had to be addressed. Educators perceived the OBE approach to education as so problematic that it has now, finally, had to be scrapped. At this stage, the National Senior Certificate (NSC) is the exit point for school leavers and serves as a benchmark for tertiary education. Standardization is the tool used to make adjustments to Grade 12 results to correct fluctuations in performance that are the results of factors within the examination processes rather than the knowledge and abilities of candidates - but this has a direct impact on the results of candidates. International benchmarking tests (e.g. TIMSS) have been introduced at the end of Grades 3, 6, and 9 to test the competency of learners in Mathematics and Science. Compared to other participating countries, the outcome for South African learners was exceedingly poor and this is seen as a reason for serious concern.
\end{abstract}

Keywords: Curriculum; Apartheid; Standardization; Benchmarking; Higher Education

INTRODUCTION

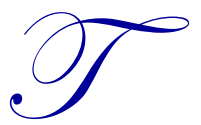

he period 1994-2011 introduced a radically new historical era for all South Africans, and most importantly, for school education (Grades 1-12) in South Africa. The political thinking in 1994 was to abolish all the old that had been systemically linked with apartheid and to introduce new policies in all the various spheres in the country (Du Plessis, 2009) as schooling had been in dire straits for many years. To add to this, there is the appalling reality that, although South Africa is the wealthiest economy on the continent, the schooling success is among the worst (Nongxa, 2010). According to Malada (2010) many previous systems had been excellent even though they might have had flaws and room for improvement, but instead of assessing what was good and building on that, the new approach was to discard tried and tested basic principles of education. The result was Outcomes-Based Education (OBE), an approach that had already failed dismally in some First World countries. Attempting to make it work in South Africa, which is partially a Third World country, was tantamount to reinventing the wheel (Lawack, 2009).

Consistent with South Africa's new constitution, the new government abolished the existing raciallydefined departments of education and established a single education system (Fiske \& Ladd, 2004). More specifically, this period can best be described as a race to establish an overarching legal and policy canopy under which education would be more appropriately conducted in the new democracy (Jansen, 2001a). This was undoubtedly a laudable enterprise, but it is an inescapable truth that education is a highly specialised field which can never be successfully served by political appointees (Roois, 2012). Many of those who were rewarded for their role in the struggle (the so-called caders) through being given senior appointments were not fit to fill highly specialised 
posts in the field of education (Lawack, 2009). Thus, following the outset of democratic rule in South Africa in April 1994, it became clear that the transition was a political one and one particularly ill-suited to the field of education.

In this article the various historical, political and curriculum changes that resulted from the post-apartheid dispensation and the dismal outcome which it produced in the educational system in South Africa, will be critically analysed and assessed.

Since 1994 there has been a significant redesigning process of the education and training landscape in South Africa. Eighteen racially-divided departments, the dismal inheritance of the previous dispensation, had to be restructured into nine provincial departments with an over-arching national department to provide coherence of policy and philosophy (Chrisholm, 2004, Harley \& Wedekind, 2004, Jansen, 2001a). It was deemed necessary that policy should be in place for transforming the national system of education and training and that the latter needed to recognise that pedagogies, curricula and qualifications were not givens, but rather that they were the result of decisions, as well as priorities, and therefore needed debating (Young \& Kraak, 2001). Furthermore, South Africa's past was analysed and the results deemed crucial for purposes of a new educational dispensation by liberal historians in terms of racial and political discrimination and domination, and by Marxist and revisionist historians in terms of class and economic domination (Hartshorne, 1999). Harley and Wedekind (2004) state that writers of different theoretical persuasions agree that there is generally a close relationship between national political visions and national curricula and nowhere is this relationship more starkly illustrated than in South Africa. It was a given that a new curriculum for a new dispensation was welcomed and unavoidable, but the bottom line was that diverse cultures, extreme backgrounds of learners, values in education, and so forth, had to be taken into account and Curriculum 2005 or OBE, as it was generally referred to, was introduced. Textbooks were replaced by workbooks and learner portfolios (Malada, 2010). Many shortcomings in the curriculum popped up and proliferated as implementation was almost impossible, expensive and disastrously teachers were ill-prepared and did not receive adequate training. Thus, learners suffered from the outset (Malada, 2010). There was widespread ignorance as the new curriculum moved away from the crucial basics like reading, writing and arithmetic to a learner-centred approach with the result that most learners at university level have now been found to struggle with reading and understanding of content at a level that would reasonably be expected of a university scholar (Blaine, 2010; Malada, 2010). At the same time, and quite paradoxically, South Africans must shake off their obsession with university education for all, making it more prized, with tougher entrance requirements (Opinion Leaders, 2012). Therefore, it was imperative that stakeholders at university level would not permit the tertiary system do go the same way as school education (Nongxa, 2010) and further research into this is imperative.

\section{AIMS AND OBJECTIVES}

The aims of this study will focus on analysing the changes in the education system in the post-1994 dispensation and comparing benchmarking trends. In the final instance, the challenges of the South African education system, if it were to be relevant for the needs of the country and its people, will be analysed.

\section{METHOD AND PROCEDURE}

The above was done by means of a literature review and the findings are presented in narrative format. Various policies, outcomes of different benchmark tests and views of critics were discussed in order to determine the current education situation in South Africa. The databases used were EBSCO, Sabinet online and various newspapers. The keywords included: school system, curriculum, apartheid, standardization, grade 12 and higher education.

\section{BACKGROUND AND HISTORICAL ANALYSIS}

\subsection{Historical overview}

Since its inception OBE had been controversial and confusing for South African educators and policymakers alike (Spreen \& Vally, 2010). What has to be kept in mind is that the powerful impulse behind progressivism 
as an educational movement was postulated and driven on the notion of social justice. Muller (2001) states that, entirely laudably, that most of progressivism's social zeal was concerned with producing equitable education outcomes for children who had been disadvantaged by state schools.

In order to understand the effect of education in this country, it is deemed necessary to take cognisance of the various demographic influences that affect education in South Africa. In terms of the Constitution of South Africa, the country is divided into nine provinces, each with its own Legislature, Premier and Provincial Members of Executive Councils. Each province features its own distinctive landscape, vegetation, climate and socio-economic issues. Especially some of these provinces are in the grip of extreme poverty where providing food and shelter is a dominant concern framing educational needs and impacting particularly negatively on and undermining education. Therefore, the need to alleviate poverty is very high on the country's socio-economic agenda. In the light of this harsh truth, obtaining a worthwhile education is seen as an opportunity to escape from poverty. The proportion of people living in poverty in South Africa has not changed significantly between 1996 and 2001 (Steyn, Steyn, De Waal, Wolhuter, 2011), and ironically, those households living in poverty have sunk deeper into poverty and the gap between rich and poor has widened by 6.3\% (Steyn et al, 2011). This fact strongly underscores the fact that alleviation of poverty should have been the starting point of the new democracy rather than the radical changes to an education system that would not alleviate the situation but rather broaden the gap between the poor and the rest of the citizens (Nongxa, 2010).

Furthermore, the prevalence of poverty in communities is often quite sadly reflected in schools within these communities. Apart from many other concerns, it is true that close to half of South Africa's schools have a shortage of classrooms (almost 65000 classrooms are needed) and 2,3 million learners attend schools without water being available within walking distance and 6.6 million learners attend schools without toilets. Only slightly more than $10 \%$ of primary schools and around a third of secondary schools have recreational and/or sports facilities (Steyn et al, 2011, Ramphele, 2012).

HIV/AIDS is also causing havoc in the country as $12.7 \%$ of all teachers had been infected with HIV/AIDS in 2004 (Malada, 2010). The influence of HIV/AIDS on human and social development is very profound. Increased illness and deaths, and reduced life expectancy affect developmental objectives. It is a well-known fact that many children in South Africa are not only heads of households, but face social problems including hunger, poverty, HIV/AIDS and violence (Spreen \& Vally, 2010). These socio-economic problems of necessity will also have a devastating influence on academic achievement (Howie, 2004).

Language in South Africa remains highly controversial and emotional. The South African Constitution, 1996 (Act 108 of 1996) (South Africa, 1996) clearly states that everyone has the right to use language and to participate in the cultural life of his choice. To cater for South Africa's diverse population, the Constitution provides for 11 official languages namely Afrikaans, English, IsiNdebele, IsiXhosa, IsiZulu, Sepedi, Sesotho, Setswana, SiSwati, Tshivenda and Xitsonga. In spite of this provision in the Constitution stating that all official languages must enjoy parity of esteem, and equal use where practicable, there is a marked move towards unilingualism in the public sector. In most government departments the medium of communication is English. This trend is also visible in official publications and documents of national importance. In educational terms, this means that mother-tongue education is increasingly sacrificed on the altar of English, often and sadly in the interests of upwards social mobility.

South Africans are therefore incredibly diverse with regard to living conditions, available resources and religious affiliation (Steyn et al, 2011). Almost $80 \%$ of South Africa's population are at least nominally of the Christian faith, with a strong interaction in many instances with traditional African religions. Other major religious groups are Hindus, Muslims and Jews. A minority of South Africa's population does not belong to any of the major religions, but regard themselves as traditionalists or of no specific religious affiliations (Steyn et al, 2011).

Although South Africa reportedly has the best developed and well-resourced system of education and training on the African continent (with the largest proportion of GDP going to education of all African countries), many adult South Africans are functionally illiterate, and many South African children are learning in school conditions which resemble those in the most impoverished states (Nongxa, 2010). In view of these circumstances, the government introduced Curriculum 2005 to alleviate the challenges as outlined. 
From the foregoing discussion it is clear that many detrimental factors from the pre-1994 dispensation are still present and according to some researchers on these matters, no significant changes have occurred (Spreen \& Vally, 2010).

\subsection{An overview of the development and implementation of Curriculum 2005}

As apartheid structures increasingly crumbled in the early 1990s, the new democracy gradually came into being and schools became less segregated. When the new democratic government assembled, one of their key strategic challenges was the rapid transformation of the school curriculum (Jansen, 2001b). Furthermore, what failed to capture the newly-elected government's attention was the fact that the countries in which outcomes-based education programmes operated, were First World countries with very broad tax bases, very favourable teacherlearner ratios, a high degree of professional education of teachers, well-resourced classrooms and critical-thinking teachers (MacDonald, 1990). Policy research shows that it does not work to rush the implementation of curriculum reform and the reason offered is that the politics of education reform wins over the pedagogy of reform (Bertram, 2011). Educational transformation was a given and the OBE approach was adopted. The main reason for this radical change was that policy-makers wanted to move away from the apartheid curriculum and address the laudable outcomes of skills, knowledge and values for social justice, equality and development (Spreen \& Vally, 2010). Harley and Wedekind (2004) felt that the ensuing change in the form of Curriculum 2005 (C2005, generally referred to as OBE) was a scale arguably unparalleled in the history of curriculum change. Thus, it could be assumed that a new approach to education would be a useful tool for changing many of the obsolete approaches such as rotelearning and learning merely to pass, which were considered devoid of any holistic content (Nair, 2003). Blade Nzimande maintains that curriculum transformation helps change society and address inequalities (SAPA, 2011).

The educational crisis must be seen against the background of South Africa's lackadaisical performance in comparative international benchmark trends in literacy and numeracy, as well as in numerous national evaluations and tests that will also be discussed in this article. Spreen and Vally (2010) mention a very important point and that is that C2005 has become shorthand for many for purposes of expressing dissatisfaction with education in South Africa.

This new approach (C2005) was launched in March 1997, with implementation in Grade 1 scheduled for 1998 and Grade 7 in 1999. C2005 was thus intended to be phased in progressively so that it would cover all sectors of schooling by 2005 (Harley \& Wedekind, 2004, Steyn et al, 2011). C2005 consists of two bands: General Education and Training (GET) (Grade 1 - Grade 9) and Further Education and Training (FET) (Grades 10-12). GET is compulsory for all learners. Furthermore, the new curriculum had three design features: Firstly, it was outcomes-based, secondly it was located in the notion of an integrated knowledge system and the third feature was the promotion of a learner-centred pedagogy. It also consisted of eight Learning Areas which replaced the traditional subjects in the GET phase. Furthermore, C2005 was a complex system of curriculum tools: It had 66 Specific Outcomes, Range Statements, Assessment Criteria, Performance Indicators, Phase Organizers and expected Levels of Performance (Young \& Kraak, 2001, Steyn et al, 2011). C2005 rejected each of the principles of the traditional curriculum. Outcomes were linked to course assignments and replaced syllabuses and terminal examinations and criterion references replaced normative-based assessment. It aimed to open up the curriculum to all children and integrate it with their experience. At the same time it tried to ensure that learners actually got access to the curriculum through a complex system of specifications as mentioned (Young \& Kraak, 2001). Thus, when Kader Asmal became minister of education in 1999, he instituted a review of Curriculum 2005, which led to the "Revised National Curriculum".

With all these features the curriculum has been criticized as being "bogged down in too much bureaucracy, academic rationality and theoretical logic" while teachers, who are directly involved in classroom practice, have become mere observers of a process driven by outside "specialists" (Hartshorne, 1999). Much of the curriculum and classroom research in the country points to the need for curriculum documents to describe much more clearly the sequence and progression on knowledge within a subject (Bertram, 2011). From the outset, irresponsible unionism made it impossible for principals to manage schools properly and communities participated nominally in school governing bodies (Malada, 2010). A major shortcoming during the implementation process was that the value of C2005 could not be assessed properly unless account was given of the day-to-day contextual realities of teaching and learning in South Africa. 
Thus, there were many implementation problems which included the following (Harley \& Wedekind, 2004):

- $\quad$ A complex curriculum policy;

- $\quad$ inadequate co-ordination and management;

- $\quad$ insufficient capacity in terms of staff and finance;

- $\quad$ inadequate teacher development; and

- $\quad$ limited curriculum development for teachers.

It goes without saying that the direction of the $\mathrm{C} 2005$ reforms remains a highly contested issue and for most critics it is seen as a seriously misbegotten endeavour (Young \& Kraak, 2001). In 2011, 65\% of Grade 3s are not competent in literacy, $72 \%$ are not meeting the standard in languages and $70 \%$ are not able to do basic mathematics (Lansdowne, 2011), this despite the fact that there was a slight increase in these results compared to the previous benchmark tests in 2009. It should be noted that international experience also shows that after spikes in performances, it tends to even out or slow down (Jones, 2011).

Cognisance should also be taken of the fact that, in the case of at least some historically advantaged schools (usually referred to as ex-model C schools ${ }^{1}$ ), the reality of the implementation of C2005 was quite the opposite of that experienced by most other schools in the country: The new curriculum for these schools merely formalised long-standing practices that had been the norm (Harley \& Wedekind, 2004). Oakes (2001) and Jansen (2001b) note that these teachers saw C2005 as having continuity with past practices in the sense that "it's what we've been doing all along". Black teachers, on the other hand, saw C2005 as something worth striving for. Ironically, C2005 review found that ex-model C schools were having less difficulty in implementing C2005 (Harley \& Wedekind, 2004) whereas the focus of the government was the upliftment of the many black disadvantaged teachers and learners. Model C schools are setting the pace for state education and are the standard-bearers of schools in South Africa (Anon, 2011). It should also be noted that many township children are clamouring to get into Model C schools and this should indeed be a reason for serious concern (Van der Merwe, 2012). Therefore, in hindsight, it seems that the newly-proposed model ironically benefited the wrong population.

Although education during the pre-1994 dispensation had had its own problems, educators have perceived the OBE approach to education as being so much more problematic that it has had to be scrapped. Furthermore, the teachers blamed what they called the "the filling of affirmative action posts", as they felt that sometimes the "wrong people", that is, people who did not qualify for such positions, were usually appointed (Rooi, 2012; Matoti, 2010). These perceptions led to the implementation of the RNCS (Revised National Curriculum Statements) in 2008 after a review had been done of C2005. In this version of C2005 the administrative tasks and curriculum tools were minimized. This meant that it was tacitly acknowledged that it was practically impossible that there could be a notion such as "own pace", as initial diagnostic assessment and benchmarking for learners were essential as a point of departure. Also, government leaders, teachers and the public had lost confidence in the public schools they regulated and taught in. They began to send their children to private schools, for they knew that quality teaching and learning had long ceased to exist in public schools (Malada, 2010:22). Also, the total number of schools in South Africa dropped between 2000 and 2010, but the number of independent schools increased 1124 in 2009 to 1399 in 2010 (Webster, 2010, SAPA, 2012, Van der Merwe, 2012). Furthermore, Steyn et al (2011) state that three serious problems were increasingly facing South African education: Quality (i.e. excellence), equity and relevance.

However, problems persisted and Minister Angie Motshekga announced a new curriculum improvement process on 6 July 2010 and once again radical changes were planned for the period from 2012-2014 (Maluleka, 2011). This revision was intended to strengthen the National Curriculum Statements in order to improve the quality of teaching and learning in schools. Changes included a reduction in subjects from eight to six for Grades 4 to 6, the compulsory introduction of an additional language from Grade 1, extended hours to focus on languages, fewer projects, the scrapping of common task assessments and a single teacher file for planning (Maluleka, 2011). This

\footnotetext{
${ }^{1}$ The term "ex model C schools" refers to white schools prior to 1996 where limited school fees were paid and School Governing Bodies played an important and constructive role.
}

(C) 2012 The Clute Institute http://www.cluteinstitute.com/ 
again led to tight timeframes for publishers to rework textbooks so that they would be ready for the implementation dates in 2012 (Bertram, 2011).

In the next section the impact of the exit point, Grade 12, will be discussed in order to critically evaluate the present education system.

\subsection{The National Senior Certificate (Grade 12)}

The National Senior Certificate (NSC) is the exit point for school leavers and therefore a benchmark for further education. School curricula are assumed to be in line with the pool of knowledge and skills needed in the corporate environment. In the previous dispensation, Grade 12 was marked by the award of the Senior Certificate but this was replaced in 2008 by the NSC with the noble intention to address the shortcomings in the education system (Nair, 2002).

In the past (prior to 2008 when the first Grade 12 National Senior Certificate was written), Grade 12 learners could pass their subjects at three different levels, viz., higher, standard or lower grade. The new curriculum offers 29 subjects at one level, consequently there is no distinction between subjects at the higher, standard or lower grade (Nel \& Kistner, 2009). For university exemption, a candidate must obtain a rating of at least 4 (50-59\%) in four school subjects from the designated list of recognised subjects for admission to university (DoE, 2005). In reality it means that a student could in fact obtain less than 50\% for all 7 subjects taken at school level without distinguishing a level (e.g. higher, standard or lower grade). The implication for universities tends to be highly problematic if not distorted, as students with a very low academic level are given the idealistic expectation that they are at the level of university scholars - because universities are increasingly setting their own entrance requirements over and above the national requirements for university admission - especially in the subjects such as engineering, where the mathematics requirements are particularly stringent.

When looking at the results of the Grade 12 examinations after 2008 it was indicated that many academics and analysts were concerned that too many learners passed Mathematics with 50\% compared with the 28156 learners who passed higher grade Mathematics at 40\% in 2006 and 28263 who passed it in 2007. They questioned whether the 2008 results at this level were comparable with higher grade passes in previous years. It was also indicated that those learners who got 50\% or more in the 2008 core Mathematics examination, would historically have passed the higher grade at $40 \%$ (Gower, 2009). This also led to a too high potential influx of students at university level and many other serious problems. Furthermore, a combination of low skills levels and poor education spelled double trouble for any nation (Malada, 2010). A further concern is the fact that $80 \%$ of South Africa's university students came from only $20 \%$ of the country's schools (Blaine, 2010). O'Connell (in Blaine, 2010) stresses the fact that it is important to distinguish competence from talent as learners are not without talent, but the problem was that they were not competent because they had not been properly taught at school.

When considering the number of passes, one should consider the retention rate of pupils. In other words, are more pupils progressing from Grade1 to 12 each year? If the throughput of pupils is improving then there should be a steady increase in the numbers at Grade 12 level. In 2010 more than 47000 pupils enrolled to write the national Senior Certificate examinations in the Western Cape, but, in 2011 the numbers were significant lower (Grant, 2011). Retention of learners has increased by 16\% from 47\% in 2009 to 53\% in 2010 and a remarkable 63\% in 2011. But, in 2009 there was a decline in the numbers passing compared to 2008.

It appeared from the first NSC matriculation results in 2008 that there was possibly an improvement in the South African education system in terms of learners who had written the final matriculation examination (589 912 candidates in 2008 compared to 564000 in 2007). Also, more learners qualified for university exemption (20\% in 2008 compared to $16 \%$ in 2007) (Nel \& Kistner, 2009). Critics like Ramphele (2009) and Jansen (in Potgieter, 2010) felt, however, that this did not reflect the true picture. Ramphele indicated that the pass rate was $62.6 \%$ for Grade 12 in 2008 whereas the South African Institution of Race Relations indicated that the real pass rate was in fact only $36.2 \%$. Furthermore, the $79 \%$ pass rate in Mathematical Literacy for a country with an extremely poor performance in Mathematics, as indicated in the TIMSS report, can be rightfully questioned (Howie, 2004). Initially it was stated by Umalusi that the extent of the adjustments made to the 2010 matric results would not be made public 
as they stated that the standardization process was "highly complex" and "very technical". Umalusi further stated that although adjustments should not exceed $10 \%$ they are allowed to exceed that when circumstances so dictate (Davies, 2011). Marks in nine 2010 papers were adjusted upwards by Umalusi and included Mathematics, Accountancy and many languages (SAPA, 2011). During the grade 12 examination in 2011 one in six pupils got less that $10 \%$ in Mathematics. More than half the matrics who wrote Physical Science got less than $30 \%$. The numbers of the 2011 examination also indicated that fewer pupils were taking critical subjects like Maths, Physical Science and Accounting (SAPA, 2011).

Nel and Kistner (2009) point out that since the differentiation between subjects at higher and standard grades has been phased out, more learners have qualified on the grounds of their subject combination (two languages, Mathematics, or Mathematical Literacy and one designated university subject) for basic admission to a university - but the issue about university-specific entrance requirements then becomes even more problematic.

Suddenly, support systems are concentrated on the matriculation examination, and people conveniently forget that it is the foundation that makes the building stronger. Poor matriculation results are a reflection of the failures of basic education (Lekota, 2012). That learners at tertiary level cannot read proficiently is partly because they failed to learn to read at a tender age (Malada, 2010). As a result university academics are concerned that firstyear students lack basic mathematical concepts that are required and state, for example, that at university level lecturers have to go through equations three times to explain simple mathematical procedures that should have been ingrained at school level (Gower, 2009, Nel \& Kistner, 2009).

\subsection{Grade 12 results and the impact of standardization}

A further process that is often misunderstood is that of standardisation as implemented by Umalusi (the body that serves as a watchdog in basic education) to make adjustments to Grade 12 results. According to Umalusi (2011) this is an essential tool, used to correct fluctuations in performance that are the result of factors within the examination processes themselves rather than the knowledge and abilities of candidates, and which, unfairly, have an impact on candidates. Jansen (in Potgieter, 2011) argues that they make adjustments in smaller subjects which would allow thousands more learners to pass Grade 12. Umalusi therefore uses standardisation to correct problems at a late stage and this makes it very difficult for anyone to understand what candidates actually achieved. This fact contributes to the general suspicion of standardisation. There is also a debate as to whether standardisation as practised by Umalusi (and the reasons for its use), is a common international practice or not and the general feeling is that results and the standardization process should be more transparent (Tlhabi, 2011). The newly-elected government have introduced their standardization measures since 1996. In other words, standardization had an influence on the "old" Senior Certificate Examination up to 2008 as well as on the "new" National Senior Certificate from 2008 onwards. The government's drive to improve the matriculation pass rate has seen the number of learners writing Mathematics and Science at the higher grade drop by more than 36000 in 1998. The overwhelming finding by the evaluators in the majority of subjects - Mathematics, Biology, History, English First Language and English Second (Additional) Language was that the examinations contained few questions that required the deployment of higher-order thinking skills. This resulted in the examinations being easier than they had been in 1992 (Mohala \& Grey, 2004). Overall the country has seen an increase in the number of learners writing the matriculation examination, while the pass rate has climbed steadily from $47 \%$ in 1997 to an all-time high in 2004 of $73 \%$. However, the number of candidates writing Mathematics and Science has dropped steadily from 1999 to 2003 (Govender \& Mkhize, 2004). The consequence of this trend is that higher education is failing to meet the demands of the South African economy. The outcome is that a high number of students enrol at education institutions and do not complete their studies on time. University dropout rates are shocking, where the graduation rate of $15 \%$ is among the lowest in the world (Malada, 2010). Each year universities are subjected to a mad rush for places and in 2012 the number of applications exceeds the number of places by 183000 . The picture is dismal if one takes into account that only $15 \%$ of registered first-years graduate in the required time (Opinion leaders, 2012).

Another reason for the improved pass rate is that selection of Grade 12 learners takes place in their Grade 11 year, so that only the more able learners are enrolling for the Grade 12 exams (Dempster, 2004, Rademeyer, 2012). In order to further create a high pass rate for Grade 12, learners are held back in Grade 11, resulting in 18\% learners who were supposed to register and did not register for Grade 12 in 2004 (Dempster, 2004). The total 
number of Grade 12 candidates has declined by about 50000 between 2000 and 2003, and anecdotal evidence indicates that many "high-risk" learners are enrolled as private candidates, which means that their results are excluded from the national results (Dempster, 2004). Angie Motshekga ordered the Limpopo Department of Education to probe allegations that authorities excluded certain pupils from registering for matric examinations in order to maintain the school's high pass rate (Maponya, 2011). Thus, the Utopian impression created of Grade12 results is indeed a reflection of: The Emperor is not naked!

It goes without saying that standardization of Grade 12 results is creating a barrier between original results and adjusted results and therefore is contributing to major discrepancies in the context of the reliability of the schooling system (Naidoo, 2004). Furthermore, the country's matriculation results have improved by $24,4 \%$ since 1999 to 2003.

The question is rightfully asked that, if, as the DoE would have the public believe, these examinations were significantly different from previous non-OBE exams, how can the previous results be used as a benchmark against which to calibrate OBE results? This would unequivocally mean that either the Grade 12 exams were significantly different or they were not. It is of great concern that the opportunity to create an accurate baseline of results is now lost, and every subsequent matriculation year will be benchmarked against these essentially inaccurate, manipulated results. It must be kept in mind that the only time a country knows how well or poorly the education system is working is when learners participate in international bench-marking exercises, such as TIMSS (Howie, 2004). South Africa has featured at or near the bottom of every such exercise since 1995 to date. C2005 or OBE has turned into a monster that calls for analytical thinking on matters about which very little content is taught. In this respect Silman (2008) states that it is ridiculous to assert that children should be critical thinkers before they have adequate factual information to consider. In order to demonstrate the distorted illusion of the schooling system in South Africa, it is important to discuss the outcomes of the TIMSS Report (Howie, 2004). This will also provide an objective method in benchmarking the South African education system.

\subsection{Benchmarking: The TIMSS Report and the outcomes of Mathematics results}

The Third International Mathematics and Science Study (TIMSS) was conducted in 1995 under the auspices of the International Association for the Evaluation of Education Achievement (IEA) (Howie, 2004). The shocking outcomes in Mathematics and Science subjects are a clear indication that our academic schooling is on the wrong track. In TIMSS the performance of the South African learners was significantly below learners in all the other 40 participating countries. This was the largest and most comprehensive international study ever undertaken of educational achievement. It involved nearly half a million Grades 4, 8 and 12 learners in nearly 50 countries and 15000 schools. Its main objectives were to compare and analyse curricula, teaching practices and student achievement in Science and Mathematics in the participating countries. The main purpose was to enable countries to determine whether they were internationally competitive, to examine the variety of best practices in successful schools, and finally, to establish world-wide benchmarks for setting and evaluating goals in Mathematics and Science. The methodology of the TIMSS testing was very broad: Not only were learners tested in the conventional way, but teaching practices were also evaluated, the role of the curriculum in teaching and learning was taken into consideration, textbooks used were considered and homework and learner attitudes were examined. Nair (2003) states that it is from this type of study that one can gain an insight into how different national educational policies can influence the achievement of learners.

In order to demonstrate the point made that South African education standards were not on par with the rest of the world, a summary of the outcomes of some of the countries participated in the TIMSS project in 1995 will follow as presented in Table 1. 
Table 1: Selected scores from the TIMSS, Grade 8 test survey based on overall mean score for the science assessment

\begin{tabular}{|l|c|c|c|c|}
\hline \multicolumn{1}{|c|}{ Country } & Overall Mean Score & All Science Content Areas & Physics & Chemistry \\
\hline Singapore & 607 & 70 & 69 & 76 \\
\hline Japan & 571 & 65 & 60 & 71 \\
\hline Netherlands & 560 & 62 & 62 & 65 \\
\hline Austria & 558 & 61 & 62 & 58 \\
\hline England & 552 & 61 & 60 & 55 \\
\hline Australia & 545 & 60 & 57 & 54 \\
\hline Russia & 538 & 58 & 57 & 57 \\
\hline Israel & 524 & 57 & 54 & 53 \\
\hline France & 498 & 54 & 48 & \\
\hline Iran & 470 & 47 & 27 & 52 \\
\hline Colombia & 411 & 39 & 27 & 26 \\
\hline South Africa (lowest score) & 326 & 27 & & 26 \\
\hline
\end{tabular}

(Howie, 2004)

It is devastating to looking at these results and realise the impact of an education system that cannot compete with standards in other countries. It must be remembered that Grade 12 results prior to 1994 were stripped of the standardization process and were not superficially inflated as after 1994 when standardization became the benchmark. Furthermore, this is a direct measurement of the academic quality of students eventually admitted into universities in the country.

TIMSS was repeated in 1998/1999 and South African learners achieved an average of 275 points out of 800, whilst the international average was 500 (Howie, 2004). Once again, South African learners performed significantly worse than those from all other participating countries. Howie (2004) indicates that learners who spoke English or Afrikaans at home tended to achieve higher scores in mathematics. In contrast, children from homes where African languages were used were more likely to achieve lower scores. Learners from poor homes were also less likely to achieve high scores in mathematics as opposed to those from wealthier families.

Thus, it can be seen that South Africa's score is extremely low and this is a reason for serious concern. It goes without saying that, influenced by such reports, government planners had once again (for the third time in 2011) embarked upon educational planning aimed at introducing modern teaching and learning models. Curriculum 2005 is based on two rejuvenating approaches that included competency-based and mastery learning. In other words, while competency-based learning aims to prepare learners for success in fulfilling various life roles, mastery learning attempts to maximise the quality of teaching and the time allowed for both teaching and learning (Nair, 2003). Although significant progress has been made with regard to administrative restructuring, policy development and infrastructural improvement, the quality of education that the majority of learners are receiving is far from satisfactory (Howie, 2004).

Thus, there are at present many challenges facing the school system in South Africa which contribute to the dismal scenario outlined above. These will not be unpacked fully here, but only indicated, as they constitute a separate investigation which might also render some proposals for improvement.

Such challenges include, but are not limited to, violence and safety in schools; the devastating effect of low moral values; the lack of community support; the persistent evil of politics in schools; truancy and its destructive effect on dropout rates; the all-pervasive effect of poverty; the nuisance of persistent late coming; the effect of the poor results in literacy and numeracy; the issue of under-performance of educators and ultimately the implications for higher education.

6 CONCLUSION

The researchers have demonstrated that education failed dismally with far-reaching consequences in education par se and in the establishment of morals and values needed for a society. It was deemed necessary to analyse the school system in South Africa holistically in order to take cognisance of the challenges that the system is facing. It is noted that it is not possible to find instant solutions to the problems brought about not only by the 
foregoing history but by the bumbling changes that have further disabled the education system. It was noted in this article that Curriculum 2005 had disastrous consequences as implementation is meant for highly developed and first world country and definitely not for a developing country that tend to react with emotional implementation of structures and policies.

\section{AUTHOR INFORMATION}

Dr. N. Mouton, North-West University, South Africa, Manager: Admissions and Records, Mmabatho, South Africa. E-mail: 10516387@nwu.ac.za (Corresponding author)

Prof. G.P. Louw, School of Post-Graduate Studies, North-West University, Mmabatho, South Africa. E-mail: 10056394@nwu.ac.za

Prof. G.L. Strydom, School of Biokinetics, Recreation and Sport Science, North-West University, Potchefstroom, South Africa. E-mail: $\underline{10172521 @ n w u . a c . z a}$

\section{REFERENCES}

1. $\quad$ Anon. (2011, June 30). Rid schools of those who bring down education. The Herald, $\mathrm{p} 20$.

2. $\quad$ Bertram, C. (2011, June 9). Rushing curriculum reform again. Mail and Guardian, p 39.

3. Blaine, S. (2010, September 20). Matrics "not ready for tertiary study". Business Day, p 4.

4. Chrisholm, L. (2004). Changing class: Education and social change, 1990-2002. Cape Town: Compress.

5. Davies, R. (2011, January 19). 2010 Matric adjustments "confidential": Umalusi. The Citizen. Retrieved from http://www.citizen.co.za/citizen/local-news

6. Department Of Education. (2005). Minimum admission requirements for Higher Certificate, Diploma and Bachelor's degree Programmes requiring a National Senior Certificate. Pretoria. August 2005.

7. $\quad$ Dempster, E. (2004, September 29). Declining standards? Natal Witness, p 10.

8. Du Plessis, T. (2009, October 2). Als was toe nie so sleg. Beeld, p 12.

9. Fiske, E. \& Ladd, H. (2004). Balancing public and private resources for basic education: School fees in post-apartheid South Africa. In L. Chisholm (Ed.). Changing Class: Education and social change in postapartheid South Africa (pp. 55-88). Cape Town: Compress.

10. Govender, P. \& Mkhize, T. (2004, October 10). Improved pass rate back fires on maths and science pupils. Sunday Times, $\mathrm{p} 1$.

11. Gower, P. (2009, May 1). Maths exam finding. The Teacher, $\mathrm{p} 5$.

12. Grant, D. (2011, December 21). Quality of education should not be determined only be matric pass rate. Cape Argus, p 19.

13. Harley, K \& Wedekind, V. (2004). Political change, curriculum change and social formation, 1990 to 2002. In L. Chisholm (Ed.). Changing Class: Education and social change in post-apartheid South Africa (pp. 195-220). Cape Town: Compress.

14. Hartshorne, K. (1999). The making of education policy in South Africa. Cape Town: Oxford University Press.

15. Howie, S. (2004). A national assessment in mathematics within an international comparative assessment. Perspectives in education. 22(2), 149-161.

16. Jansen, J. (2001a). Image-ing teachers: Policy images and teacher identity in South African Classroom. South African Journal of Education, 21 (4), 242-246.

17. Jansen, J. (2001b). Rethinking education policy making in South Africa. In Kraak, A \& Young, M., (Eds.) Education in Retrospect (pp. 41-58). Johannesburg: Ultra Litho (Pty) Limited.

18. Jones, M. (2011, June 20). High school dropout rate shock. Daily News, p 5.

19. Landsdowne, A. (2011, July 04). ANC has lost the plot on priorities for SA youth. Cape Argus, p 12.

20. Lawack, J. (2009, November 30). OBE won't be missed when it's phased out of schools. The Herald, p 7.

21. Lekota, M. (2012, July 5). Zuma's race talk amounts to a failure to uphold constitution. The Star, p 24.

22. MacDonald, C.A. (1990). Standard Three general science research 1987-1988. A final report of the Threshold project. Pretoria: HSRC.

23. Malada, B. (2010, September 19). We ignore proper education at our peril. Sundae Tribune, p 22. 
24. Maluleka, S. (2011, August 10). Curriculum: back to the blackboard. Daily News, p 3.

25. Maponya, F. (2011, December 01). School probed for ejecting matric pupils. Sowetan, p 2.

26. Matoti, S.N. (2010). The unheard voices of educators: perceptions of educators about the state of education in South Africa. South African Journal of Higher Education, 24(4), 568-584.

27. Mohala, T \& Grey, J. (2004, October 7). Mail and Guardian, p 3.

28. Muller, J. (2001). Progressivism redux: Ethos, policy, pathos. Introduction. In Kraak, A. \& Young, M., (Eds.) Education in Retrospect (pp 59-72). Johannesburg: Ultra Litho (Pty) Limited.

29. Nongxa, L. (2010, August 1). Tertiary institutions ignore primary lessons at their peril. Sunday Times, p 11.

30. Kraak, A \& Young, M., (Eds.) Education in Retrospect (pp. 59-72). Johannesburg: Ultra Litho (Pty) Limited.

31. Naidoo, S. (2004, January 7). Maths and science results adjusted upwards. Business Day, p 3.

32. Nair. P.A.P. (2002). A theoretical framework for an access programme encompassing further education training: Remedy for educational waste? South African Journal for Higher Education, 16(2), 94-103.

33. Nair, P.A.P. (2003). Can prior learning experience serve as a catalyst in the paradigm shift from traditional teaching methodology to outcomes-based educational practice?: Perspectives on higher education. South African Journal of Higher Education, 17(2), 68-78.

34. Nel, C. \& Kistner, L. (2009). The National Senior Certificate: Implications for access to higher education. South African Journal of Higher Education, 23 (5), 953-973.

35. $\quad$ Oakes, I. (2001). Difficulties experienced by educators implementing Curriculum 2005. Pietermaritzburg: University of Natal School of Education

36. Opinion Leaders (2012, January 11). Stop this mad rush for varsities. The Citizen. Retrieved from http://www.citizen.co.za/citizen/content/local-news

37. Potgieter, M. (2010, February 19). Skoksyfers oor gr. 6 leerders. Burger, p 1.

38. Potgieter, M. (2011, February 3). Matriekslaagsyfer "aangepas om duisende te laat slaag". Burger, p 6.

39. Rademeyer, A. (2012, April 14). Te veel SA leerlinge herhaal, val uit grade. Beeld, p 10.

40. Ramphele, M. (2009, January 18). Another generation betrayed. The Times, p 5.

41. Ramphele, M. (2012, July 4). Partnerships can help SA teaching. The Star, p 12.

42. Rooi, J. (2012, July 8). Praat gaan SA net so ver kry. Rapport, p 2.

43. South African Press Association (SAPA). (2011, February, 23). Marks of nine DBE papers increased, 10 decreased. The Citizen. Retrieved from http://citizen.co.za/citizen/content/en/local-news

44. South African Press Association (SAPA). (2012, February 29). Fewer SA schools: survey. The Citizen. Retrieved from http://citizen.co.za/citizen/content/local-news

45. Silman, D. (2008, December 3). Education results are manipulated, with true picture heavily obscured. Star, $\mathrm{p} 10$.

46. South Africa. (1996). Constitution of the Republic of South Africa.

47. Spreen C.A. \& Vally, S. (2010). Outcomes-based education and its (dis)contents: Learner-centred pedagogy and the education crisis in South Africa. Southern African Review of Education with Education with Production, 16(1), 39-58.

48. Steyn, H.J., Steyn, S.C., De Waal, E.A.S, Wolhuter, C.C. (2011). South African Education System, Keurkopie: Potchefstroom.

49. Tlhabi, R. (2011, February 25). Public's trust in Umalusi wiped out. Sowetan, p 19.

50. Umalusi Report. (2011). Why Umalusi standardises results, and how. Umalusi: Pretoria.

51. Van der Merwe, C. (2012, July 8). Profiting from quality education. Business Times, p 6.

52. Young, M \& Kraak, A. (2001). Introduction. In Kraak, A \& Young, M., (Eds.) Education in Retrospect (pp. 1-16). Johannesburg: Ultra Litho (Pty) Limited. 


\section{NOTES}

